\title{
SWINE MARKER SW967 AS A PROMISING GENETIC MARKER FOR RABBIT MEAT PRODUCTION-RELATED TRAITS
}

\author{
G.F. Gouda ${ }^{1}$, O.Y. Abdallah ${ }^{1}$, A.R. Shemeis ${ }^{1}$ and A.Z.E. Abdelsalam ${ }^{2}$ \\ 1- Animal Production Department, Faculty of Agriculture, Ain Shams University, \\ Shoubra El-Kheima, Cairo, Egypt, 2- Faculty of Biotechnology, Misr University \\ for Science and Technology, Six October City, Cairo, Egypt
}

\section{SUMMARY}

Reciprocal crossing between three rabbit breeds viz., Flemish Giant, New Zealand White and Papillon was made and the $F_{1}$ crossbreds were intermated within each genotype and produced the $F_{2}$ crossbreds. A minimum of 7 individuals per genotype were slaughtered and DNA was isolated. DNA amplification was performed using primers for two identified genetic markers from swine to investigate their association with meat production-related genes in rabbits. Specific-PCR profile analyses revealed two alleles for swine marker SW967 with ML ranged from 63 to 110 bp. The swine marker SW967 affected significantly dressing percentage, dissected side muscle percentage, dissected side bone percentage, dissected side muscle weight to dissected side bone weight ratio and dissected side bone weight occurring in foreleg cut. This work showed the possibility of using genetic markers from swine to improve muscling traits in rabbits through marker assisted-selection.

Keywords: Rabbits, meat production-related genes, genetic markers

\section{INTRODUCTION}

To achieve real progress in production traits, many generations of selective breeding are required which could be costly and time-consuming and sometimes as in the case of carcass traits are not very effective (Visscher and Haley, 1998). However, genetic progress in quantitative traits may be further enhanced by molecular genetics either by direct selection on genes that affect traits of interest or through selection on genetic markers linked to quantitative trait loci and used in marker-assisted selection (Geldermann, 1976; Soller and Bekmann, 1983; Beever et al., 1990). Fortunately, a large proportion of markers isolated in one species could be used in other closely related species (Moore et al., 1991). Until now, rabbits suffer from a scarcity of literature on the association of genetic markers with meat production-related traits.

The purpose of this paper was to investigate the detection of genetic markers associated with rabbit meat production-related traits, which could be used as a corner stone for future marker-assisted selection in this species.

\section{MATERIAL AND METHODS}

\section{Breed groups:}

At the private El-Qanater Rabbit Farm (20km north of Cairo), three rabbit breeds viz., Flemish Giant (F), New Zealand White (N) and Papillon (P) were considered in this study.

Issued by The Egyptian Society of Animal Production 


\section{Experimental animals:}

Each of the three breed groups was composed of one buck and three does taken randomly from the stock.

\section{$F_{1}$ production scheme:}

In March-April 2001, reciprocal crossing system between breed groups was made. $\mathrm{F}_{1}$ were symbolized as: (FN), (FP), (NF), (NP), (PF) and (PN).

\section{$F_{2}$ production scheme:}

In October-November 2001, the $F_{1}$ crossbreds were intermated within each genotype group for one generation. $\mathrm{F}_{2}$ genotypes were symbolized as (FN-FN), (FPFP), (NF-NF), (NP-NP), (PF-PF) and (PN-PN). However, there were too few animals from the $(\mathrm{FN}-\mathrm{FN})$ genotype and it was excluded from the study.

\section{Management:}

After kidding, litters were kept with their dams in breeding batteries till weaning at 28 days of age, by which time they were ear tagged, sexed, weighed and transferred to wired cages. Dams and weaners were fed ad. libitum a commercial pelleted diet containing $18.5 \%$ crude protein, $14 \%$ crude fiber and $3.2 \%$ crude fat, providing $2800 \mathrm{Kcal}$ digestible energy $/ \mathrm{kg}$ diet.

\section{Meat production-related traits:}

At marketing age (90 days), a minimum number of 7 individuals per genotype were fasted for twelve hours and transferred to the Meat Laboratory where animals were weighed (fasted slaughter weight). After slaughtering, animals were dressed out then the hot carcass, skin, head, ears, feet, tail, heart, lungs plus trachea, liver, spleen, kidneys and empty digestive tract were weighed separately. Dressed carcasses were packed in polyethylene bags and deep frozen at $-18^{\circ} \mathrm{C}$ for one week. Offals were grouped into external (head, ear, feet, tail, and skin) and internal organs (heart, lungs plus trachea, liver, spleen, kidneys and empty digestive tract). The dressing outrelated traits were calculated as a percentage of fasted slaughter weight. After being thawed, carcasses were split into right and left sides. The right sides were jointed into four cuts (Blasco et al., 1992), viz., hind leg, fore leg, loin and thoracic cage cut and weighed separately. The sum of the weights of side cuts gave the jointed side weight. Side weight distribution between cuts was expressed as percentage carcass side weight occurring in each cut. Each cut was dissected into muscle, fat and bone and their weights were recorded. The sum of a tissue weight over all the cuts gave the dissected side muscle weight (DSMW), dissected side fat weight (DSFW) and dissected side bone weight (DSBW). The sum of DSMW, DSFW and DSBW gave the dissected side weight (DSW). Side composition traits were expressed as a percentage of each tissue of DSW. Side meatiness traits were expressed as muscle to bone and muscle to fat ratios at the side level. Side muscle, fat and bone weight distribution between cuts were expressed by calculating percentage dissected side muscle, fat and bone weight occurring in each cut, respectively.

\section{Genetic markers:}

After isolating genomic DNA (Sambrook et al., 1989), two identified genetic markers, from swine, were used to investigate their association with loci in connection with meat production-related traits. Table 1 summarizes information of the 2 markers considered in the present experiment. 
Table 1. Information on the Swine markers used in this experiment

\begin{tabular}{lcc}
\hline \multicolumn{1}{c}{ Species } & SWC9 & Marker \\
\cline { 2 - 3 } & 2 & SW967 \\
\hline $\begin{array}{l}\text { Chromosome no } \\
\text { No. of alleles }\end{array}$ Primers $^{*}$ & 17 & 5 \\
Size (bp) & GGCTCAGGGATCCCACAG & AGCAGACTGTTCATCTGTTCAG \\
Meat production- & AAGCACCTGTACCCACACG & GGGGCAGCTGAAAAGTCC \\
related traits in & 224-246 & 95-115 \\
connection with the & Muscle mass & Average Daily gain \\
marker-associated & & \\
loci & & \\
Reference & & Casas-Carrillo et al., 1997
\end{tabular}

*: for each marker the upper primer is the forward and the lower one is the reverse.

\section{Polymerase chain reaction (PCR) conditions:}

DNA amplification (Table 2) was performed (Williams et al., 1990) using specific primers (synthesized by Metabion, Germany) for the considered markers. The components of PCR reaction are given in Table (3) together with their amounts totaling to $25 \mu 1$.

Table 2. PCR conditions used for each of the four primers of the two markers used in the present experiment

\begin{tabular}{|c|c|c|}
\hline \multirow[t]{2}{*}{ Species } & \multicolumn{2}{|c|}{ Marker } \\
\hline & SWC9 & SW967 \\
\hline Initial separation & $94^{\circ} \mathrm{C}-5 \mathrm{~min}$ & $94^{\circ} \mathrm{C}-5 \mathrm{~min}$ \\
\hline $\begin{array}{l}\text { Temperature time duration } \\
\text { for cycle steps }\end{array}$ & & \\
\hline Denaturation & $94^{\circ} \mathrm{C}-40 \mathrm{sec}$ & $94^{\circ} \mathrm{C}-40 \mathrm{sec}$ \\
\hline Annealing & $58^{\circ} \mathrm{C}-40 \mathrm{sec}$ & $58^{\circ} \mathrm{C}-40 \mathrm{sec}$ \\
\hline Extension & $72^{\circ} \mathrm{C}-40 \mathrm{sec}$ & $72^{\circ} \mathrm{C}-40 \mathrm{sec}$ \\
\hline Final extension & $72^{\circ} \mathrm{C}-40 \mathrm{~min}$ & $72^{\circ} \mathrm{C}-40 \mathrm{~min}$ \\
\hline No. of cycles & 35 & 35 \\
\hline Reference & $\begin{array}{c}\text { http://www.marc.usda.gov.s } \\
\text { wine }\end{array}$ & http://www.marc.usda.gov.swine \\
\hline
\end{tabular}

Table 3. Components used in PCR reaction (Williams et al., 1990)

\begin{tabular}{lcc}
\hline Component & Concentration & Amount \\
\hline Genomic DNA & $25 \mathrm{ng}$ & $2.0 \mu \mathrm{l}$ \\
Forward primer & 10 Pico-mol & $1.0 \mu 1$ \\
Reverse primer & 10 Pico-mol & $1.0 \mu 1$ \\
Bioron's DNTPs & - & $2.5 \mu 1$ \\
Bioron's buffer (10X) mixed with $\mathrm{MgCl}_{2}$ & - & $2.5 \mu 1$ \\
Bioron's Taq DNA polymerase (250U) & - & $0.2 \mu 1$ \\
Distilled water & - & $15.8 \mu \mathrm{l}$ \\
\hline
\end{tabular}

\section{Gel electrophoresis and visualization of DNA bands:}

The specific PCR products were resolved by electrophoresis in 2\% agarose gel at 100 volts for 30-45 minutes using TBE buffer (5.5g Boric Acid, $10.8 \mathrm{~g}$ Tris and $4 \mathrm{ml}$ Edta $0.5 \mathrm{M}$ adjusted to $\mathrm{pH} 8$; the final volume was made up to 1 liter with distilled 
water). The gel was stained with $0.2 \mu \mathrm{g} / \mathrm{ml}$ ethidium bromide and examined on ultraviolet transilluminator.

\section{Densitometric scanning and analysis:}

PCR product gels were scanned using Bio-Rad Gel Doc 2000 and analysed with the Quantity One Software package supplied by the manufacturer.

\section{Statistical analysis:}

The data were analysed according to the following linear model (SAS, 1994): where:

$$
\mathrm{Y}_{\mathrm{ijklm}}=\mu+\mathrm{G}_{\mathrm{i}}+\mathrm{GE}_{\mathrm{j}}+\mathrm{S}_{\mathrm{k}}+\mathrm{M}_{\mathrm{l}}+\mathrm{e}_{\mathrm{ijklm}}
$$

$\mathrm{Y}_{\mathrm{ijklm}}=$ the observation on the $\mathrm{m}^{\text {th }}$ rabbit of the $\mathrm{i}^{\text {th }}$ cross type, $\mathrm{j}^{\text {th }}$ generation, $\mathrm{k}^{\text {th }}$ sex and $1^{\text {th }}$ marker;

$\mu \quad=$ the overall mean;

$\mathrm{G}_{\mathrm{i}}=$ the fixed effect of the $\mathrm{i}^{\text {th }}$ cross type $(\mathrm{i}=1,2, \ldots .5)$;

$\mathrm{GE}_{\mathrm{j}} \quad=$ the fixed effect of the $\mathrm{j}^{\text {th }}$ generation $(\mathrm{j}=1,2$, i.e. $\mathrm{F} 1 \mathrm{vs} . \mathrm{F} 2)$;

$\mathrm{S}_{\mathrm{k}}=$ the fixed effect of the $\mathrm{k}^{\text {th }} \operatorname{sex}(\mathrm{k}=1,2)$;

$\mathrm{M}_{1}=$ the fixed effect of the $1^{\text {th }}$ marker $(1=1,2)$;

$\mathrm{e}_{\mathrm{ijklm}}=$ the random error assumed to be N.I.D $\left(0, \sigma^{2} \mathrm{e}.\right)$.

The results were examined to identify those genetic markers which are associated with meat production-related traits.

\section{RESULTS AND DISCUSSION}

\section{Detection of genetic markers:}

The swine marker SW967 was able to produce in rabbits informative polymorphic products resolvable by agarose electrophoresis. Swine and rabbits are known to have common taxonomical grounds in being multi-parous and non-gastric species.

\section{Swine marker SW967:}

The results of specific-PCR profile analyses using swine marker SW967 are illustrated in Figure 1. This marker revealed a total of two alleles with molecular length (ML) ranged from 63 to $110 \mathrm{bp}$ in the five rabbit genotypes.

\section{Association of swine marker SW967 with rabbit meat production-related traits:}

For each of the 32 traits, the effect of the marker has been tested and comparisons $\left(\mathrm{C}_{2}-\mathrm{C}_{1} / \mathrm{C}_{1}\right)$ between carriers of one $\left(\mathrm{C}_{1}\right)$ and two alleles $\left(\mathrm{C}_{2}\right)$ were also tested wenever the main effect was statistically significant at $\mathrm{P}<0.05$.

\section{Body traits:}

In Table (4) the marker SW967 did not affect significantly any body trait.

\section{Carcass attributes:}

Table 5 shows significant effect $(\mathrm{P}<0.05)$ of the SW967 marker on dressing percentage, dissected side muscle percentage, dissected side bone percentage, dissected side muscle weight to dissected side bone weight ratio and dissected side bone weight occurring in foreleg cut. The marker explains $13.23 \%, 15.31 \%, 11.32 \%$, 13.79 and 8.85 of the phenotypic variation of such trait, respectively. It is noteworthy that the number of alleles had significant $(\mathrm{P}<0.05)$ positive effect on dressing percentage, dissected side muscle percentage, dissected side muscle weight to 
dissected side bone weight ratio and dissected side bone weight occurring in foreleg cut $\left[\left(\mathrm{C}_{2}-\mathrm{C}_{1}\right) / \mathrm{C}_{1}:+6.61 \%,+1.36,+8.79,+3.57\right.$ and +3.57 , respectively $]$ and significant $(\mathrm{P}<0.05)$ negative effect on dissected side bone percentage $\left[\left(\mathrm{C}_{2}-\mathrm{C}_{1}\right) / \mathrm{C}_{1}\right.$ : -7.32]. Previous reports (Gouda, 1998; Lukefahr et al., 1989; Lukefahr et al., 1983; Lukefahr et al., 1982) demonstrated that dressing percentage, muscle percentage, bone percentage and muscle to bone ratio are genetically inter-related.

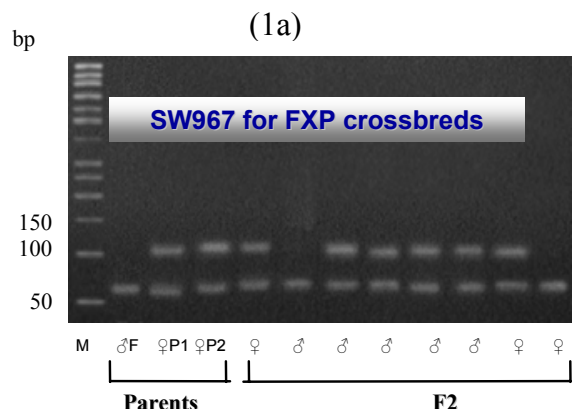

(1c)

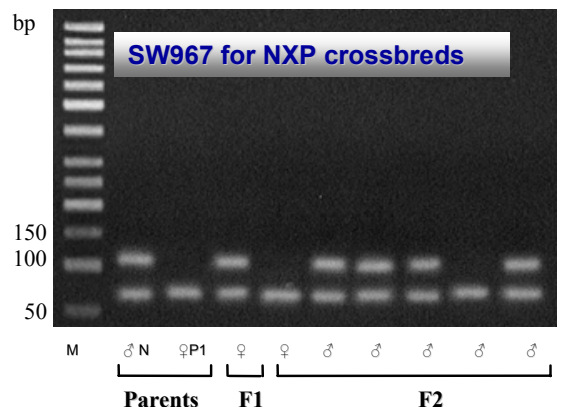

(1e) (1b)
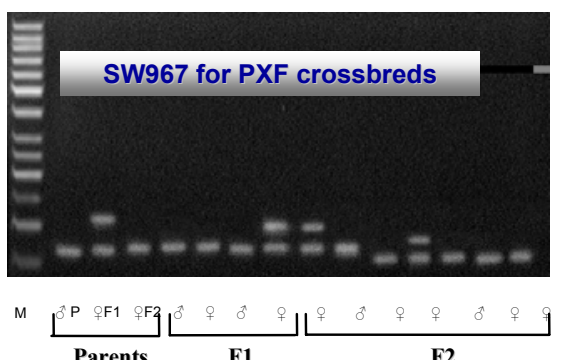

(1d)

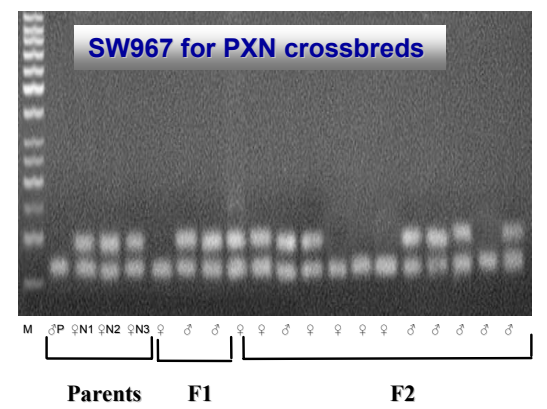

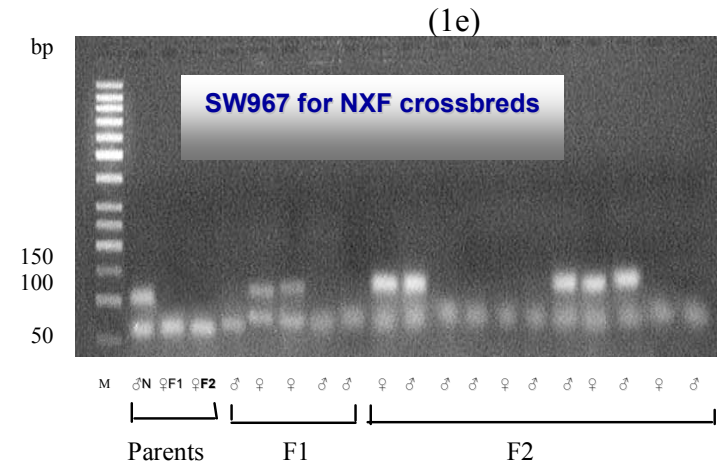

Figure 1. DNA polymorphism based on specific-PCR analysis of marker SW967 (1a) : FxP crossbreds , (1b) : PxF crossbreds

(1c) : NxP crossbreds, (1d) : PxN crossbreds $\quad$ (1e) : NxF crossbreds 
Gouda et al. 
Gouda et al. 


\section{CONCLUSION}

Considering all the data obtained in the present study it can be concluded that swine marker SW967 proved to be a promising genetic marker for muscling traits in rabbits to achieve a higher genetic gain through marker-assisted selection.

\section{REFERENCES}

Beever, J.E., P.D. George, R.L. Fernando, C.J. Stormont and H.A. Lewin, 1990. Associations between genetic markers and growth and carcass traits in a parental halfsib family of Angus cattle. Journal of Animal Science, 68: 337-344.

Blasco, A., J. Ouhayoun and G. Masoero, 1992. Study of rabbit meat and carcass criteria and terminology. Journal of Applied Rabbit Research, 15: 775-786.

Casas-Carrillo, E., A. Prill-Adams, S.G. Price, A.C. Clutter and B.W. Kirkpatrick, 1997. Relationship of growth hormone and insulin-like growth factor-1 genotypes with growth and carcass traits in swine. Animal Genetics, 28: 28-93.

Geldermann, H., 1976. Investigations on inheritance of quantitative characteristics in animals by gene markers. II. Expected effects. Theoretical and Applied Genetics, 47: 1 .

Gouda, G.F., 1998. Possibilities of changing body composition by selection. M.Sc. Thesis, Faculty of Agriculture, Ain Shams University, Cairo, Egypt.

Lukefahr, S., W.D. Hohenboken, P.R. Cheeke, N.M. Patton and W.H. Kennick, 1982. Carcass and meat characteristics of Flemish Giant and New Zealand White purebred and terminal-cross rabbits. Journal of Animal Science, 54:1169-1174.

Lukefahr, S., W.D. Hohenboken, P.R. Cheeke and N.M. Patton, 1983. Appraisal of nine genetic groups of rabbits for carcass and lean yield traits. Journal of Animal Scince, 57:899-907.

Lukefahr, S.D., C.V. Nwosu and D.R. Rao, 1989. Cholesterol level of rabbit meat and trait relationships among growth, carcass and lean yield performances. Journal of Animal Science, 67:2009-2017.

Moore, S.S., L.L. Sargeant, T.J. King, J.S. Mattick, M. Georges and D.J.S. Hetzel, 1991. The conservation of dinucleotide microsatellites among mammalian genomes allows the use of heterologous PCR primer pairs in closely related species. Genomics, 10: 654-660.

Nezer, C., L. Moreau, B. Brouwers, W. Coppieters, J. Detilleux, R. Hanset, L. Karim, A. Kvasz, P. Leroy, and M. Georges, 1999. An imprinted QTL with major effect on muscle mass and fat deposition maps to the IGF2 locus in pigs. Nature Genetics, 21: 155-156.

Sambrook, J., E.F. Fritsch, and T. Maniatis, 1989. Molecular cloning: a laboratory manual, Cold Spring Harbor Laboratory Press, New York.

SAS Institute. 1994. SAS / STAT User's Guide: Statistics. Ver. 6.04, Fourth Edition SAS Institute Inc., Cary, NC.

Soller, M. and J.S. Beckmann, 1983. Genetic polymorphism in varietal identification and genetic improvement. Theoretical and Applied Genetics, 67: 25-33.

Visscher, P.M. and C.S. Haley, 1998. Strategies for marker-assisted selection in pig breeding programmes. $6^{\text {th }}$ World Congress on Genetics Applied to Livestock Production. 11-16 January, Armidale, Australia.

Williams, J.G.K., A.R. Kubelik, K.J. Livak, J.A.I. Rafalsk, and S.V. Tingey, 1990. DNA polymorphisms amplified by arbitrary primers are useful as genetic markers. Nucleic Acid Research, 18: 6531-6535. 


\section{كثاف الخنازير SW967 ككثاف وراثى واعد للصفات المرتبطة بإنتاج اللحم فى الأرانب}

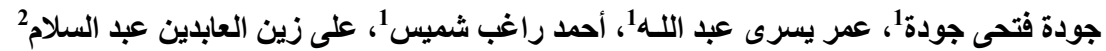

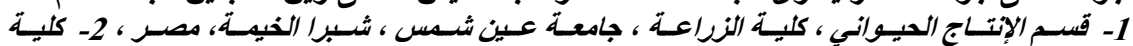

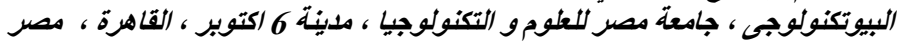

أجرى خلط تبادلى بين ثلاث سلالات من الأرانب هى الفليمش جاينت و النيوزيلندى الأبيض و البابيون

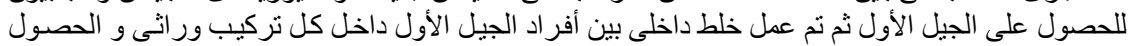

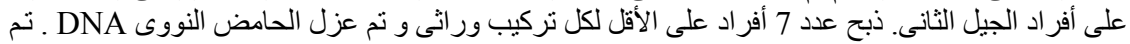

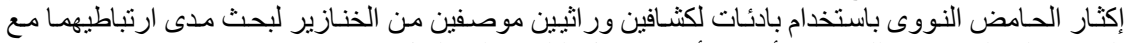

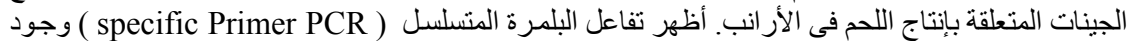

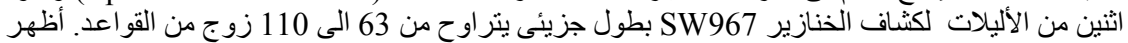

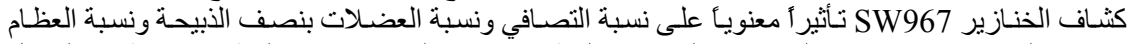

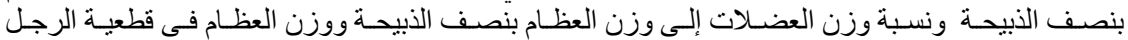

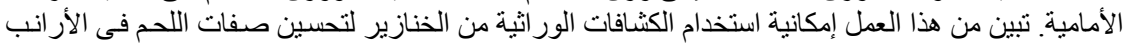

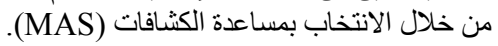


Table 4. Effect of SW967 marker on body traits and comparisons between carries of one allele $\left(C_{1}\right)$ and two alleles $\left(C_{2}\right)$

\begin{tabular}{|c|c|c|c|c|c|c|}
\hline \multirow[b]{2}{*}{ Body Traits } & \multirow[b]{2}{*}{$\begin{array}{l}\text { Overall } \\
\text { mean }\end{array}$} & \multirow[b]{2}{*}{$\begin{array}{c}\text { Marker } \\
\text { effect } \\
(P<0.05)\end{array}$} & \multicolumn{2}{|c|}{$\begin{array}{l}\text { Least square means } \\
\text { for the groups }\end{array}$} & \multirow{2}{*}{$\begin{array}{c}\text { Relative } \\
\text { deviation } \\
{\left[100\left(C_{2^{-}}\right.\right.} \\
\left.\left.\left.C_{1}\right) / C_{1}\right)\right]\end{array}$} & \multirow{2}{*}{$\begin{array}{l}\text { Percentage total } \\
\text { variation } \\
\text { in the } \\
\text { trait explained } \\
\text { by } \\
\text { the marker }\end{array}$} \\
\hline & & & $\begin{array}{c}\text { exhibited } \\
\text { two alleles } \\
\left(\mathrm{C}_{2}\right)\end{array}$ & $\begin{array}{c}\text { exhibited one } \\
\text { allele } \\
\left(C_{1}\right)\end{array}$ & & \\
\hline \multicolumn{7}{|c|}{ i. Body weight (g) at age (days) of weaning (WW) and slaughtering (SW) } \\
\hline SW90 & $1628.0 \pm 36.2$ & ns & $1686.05 \pm 53.03$ & $1697.79 \pm 59.32$ & 0.04 & -0.69 \\
\hline \multicolumn{7}{|c|}{$\begin{array}{l}\text { ii. Body linear measurements (cm) at slaughter age (90 days): length of body (BL); width of loin (LW); girth of chest (CG) and } \\
\text { round (RG) }\end{array}$} \\
\hline $\mathrm{BL}$ & $32.0 \pm 0.34$ & ns & $32.05 \pm 0.50$ & $31.15 \pm 0.56$ & +2.89 & 0.23 \\
\hline LW & $4.9 \pm 0.06$ & ns & $5.00 \pm 0.10$ & $4.89 \pm 0.11$ & +2.25 & 2.71 \\
\hline $\mathrm{CG}$ & $23.3 \pm 0.21$ & ns & $23.40 \pm 0.33$ & $23.72 \pm 0.37$ & -1.35 & 0.88 \\
\hline
\end{tabular}

ns: non significant 
Table 5. Effect of SW967 marker on carcass attributes and comparisons between carries of one allele $\left(C_{1}\right)$ and two alleles $\left(C_{2}\right)$

\begin{tabular}{|c|c|c|c|c|c|c|}
\hline \multirow[b]{2}{*}{ Carcass attributes } & \multirow[b]{2}{*}{$\begin{array}{c}\text { Overall } \\
\text { mean }\end{array}$} & \multirow[b]{2}{*}{$\begin{array}{c}\text { Marker } \\
\text { effect } \\
(\mathbf{P}<\mathbf{0 . 0 5})\end{array}$} & \multicolumn{2}{|c|}{$\begin{array}{l}\text { Least square means } \\
\text { for the groups }\end{array}$} & \multirow{2}{*}{$\begin{array}{c}\text { Relative } \\
\text { deviation } \\
{\left[100\left(C_{2}-\right.\right.} \\
\left.\left.\left.C_{1}\right) / C_{1}\right)\right]\end{array}$} & \multirow{2}{*}{$\begin{array}{c}\text { Percentage } \\
\text { total } \\
\text { variation } \\
\text { in the } \\
\text { trait explained } \\
\text { by } \\
\text { the marker }\end{array}$} \\
\hline & & & $\begin{array}{c}\text { exhibited } \\
\text { two alleles } \\
\left(C_{2}\right)\end{array}$ & $\begin{array}{c}\text { exhibited one } \\
\text { allele } \\
\left(C_{1}\right)\end{array}$ & & \\
\hline i. Dressing-out traits & & & $51.30 \pm 0.67$ & $48.12 \pm 0.75$ & +6.61 & 13.23 \\
\hline a. Dressing percentage & $50.97 \pm 0.54$ & * & $4.69 \pm 0.19$ & $5.12 \pm 0.21$ & -8.40 & 3.01 \\
\hline b. Giblets percentage & $4.59 \pm 0.15$ & ns & $22.32 \pm 0.29$ & $21.73 \pm 0.32$ & +2.72 & 3.70 \\
\hline c. External organs percentage & $22.35 \pm 0.19$ & ns & $12.07 \pm 0.38$ & $12.55 \pm 0.43$ & -3.82 & 1.05 \\
\hline d. Internal organs percentage & $11.70 \pm 0.29$ & ns & $51.30 \pm 0.67$ & $48.12 \pm 0.75$ & +6.61 & 13.23 \\
\hline \multicolumn{7}{|l|}{ ii. side cutting-out traits } \\
\hline \multicolumn{7}{|c|}{ Side weight distribution between cuts percentage jointed side weight occurring in: } \\
\hline e. hind leg cut & $39.12 \pm 0.18$ & ns & $38.94 \pm 0.24$ & $39.23 \pm 0.27$ & -0.74 & 1.07 \\
\hline f. fore leg cut & $19.46 \pm 0.09$ & ns & $19.42 \pm 0.12$ & $19.19 \pm 0.13$ & +1.20 & 1.99 \\
\hline g. loin cut & $32.58 \pm 0.17$ & $\mathrm{~ns}$ & $32.91 \pm 0.25$ & $32.40 \pm 0.28$ & +1.57 & 3.34 \\
\hline h. thoracic cage cut & $8.84 \pm 0.12$ & $\mathrm{~ns}$ & $8.73 \pm 0.16$ & $9.16 \pm 0.18$ & $\begin{array}{c}-4.69 \\
\end{array}$ & 4.79 \\
\hline \multicolumn{7}{|l|}{ iii. Side tissue dissecting traits } \\
\hline \multicolumn{7}{|l|}{ Side composition } \\
\hline $\begin{array}{l}\text { i. dissected side muscle } \\
\text { percentage }\end{array}$ & $83.21 \pm 0.18$ & $*$ & $83.58 \pm 0.23$ & $82.46 \pm 0.26$ & +1.36 & 15.31 \\
\hline j. dissected side fat percentage & $3.83 \pm 0.61$ & ns & $4.01 \pm 0.26$ & $4.15 \pm 0.29$ & -3.37 & 0.27 \\
\hline k. dissected side bone percentage & $12.96 \pm 0.18$ & * & $12.40 \pm 0.26$ & $13.38 \pm 0.29$ & -7.32 & 11.32 \\
\hline \multicolumn{7}{|l|}{ Side meatiness } \\
\hline $\begin{array}{l}\text { 1. dissected side muscle weight to } \\
\text { dissected side bone weight ratio }\end{array}$ & $6.49 \pm 0.09$ & * & $6.81 \pm 0.13$ & $6.26 \pm 0.14$ & +8.79 & 13.79 \\
\hline $\begin{array}{l}\text { m. dissected side muscle weight } \\
\text { to dissected side fat weight ratio }\end{array}$ & $24.41 \pm 1.30$ & ns & $23.87 \pm 2.10$ & $22.79 \pm 2.35$ & +4.74 & 0.26 \\
\hline
\end{tabular}


Table 5. Cont.

\begin{tabular}{|c|c|c|c|c|c|c|}
\hline \multirow[b]{2}{*}{ Carcass attributes } & \multirow[b]{2}{*}{$\begin{array}{c}\text { Overall } \\
\text { mean }\end{array}$} & \multirow[b]{2}{*}{$\begin{array}{c}\text { Marker } \\
\text { effect } \\
(\mathbf{P}<\mathbf{0 . 0 5})\end{array}$} & \multicolumn{2}{|c|}{$\begin{array}{l}\text { Least square means } \\
\text { for the groups }\end{array}$} & \multirow{2}{*}{$\begin{array}{c}\text { Relative } \\
\text { deviation } \\
{\left[100\left(C_{2^{-}}\right.\right.} \\
\left.\left.\left.C_{1}\right) / C_{1}\right)\right]\end{array}$} & \multirow{2}{*}{$\begin{array}{c}\text { Percentage } \\
\text { total } \\
\text { variation } \\
\text { in the } \\
\text { trait explained } \\
\text { by } \\
\text { the marker } \\
\end{array}$} \\
\hline & & & $\begin{array}{c}\text { exhibited } \\
\text { two alleles } \\
\left(C_{2}\right)\end{array}$ & $\begin{array}{c}\text { exhibited one } \\
\text { allele } \\
\left(C_{1}\right)\end{array}$ & & \\
\hline \multicolumn{7}{|c|}{$\begin{array}{l}\text { Side muscle weight distribution between cuts expressed as } \\
\text { percentage dissected side muscle weight occurring in: }\end{array}$} \\
\hline n. hind leg cut & $39.76 \pm 0.17$ & $\mathrm{~ns}$ & $39.55 \pm 0.24$ & $39.89 \pm 0.27$ & -0.85 & 1.46 \\
\hline o. fore leg cut & $18.47 \pm 0.12$ & ns & $18.29 \pm 0.16$ & $18.19 \pm 0.18$ & +0.55 & 0.07 \\
\hline p. loin cut & $34.50 \pm 0.19$ & ns & $34.87 \pm 0.28$ & $34.29 \pm 0.31$ & +1.69 & 3.47 \\
\hline q. thoracic cage cut & $7.27 \pm 0.01$ & ns & $7.28 \pm 0.15$ & $7.62 \pm 0.17$ & -4.46 & 3.43 \\
\hline \multicolumn{7}{|c|}{$\begin{array}{l}\text { Side fat weight distribution between cuts expressed as percentage dissected side } \\
\text { fat weight occurring in: }\end{array}$} \\
\hline r. hind leg cut & $24.26 \pm 0.83$ & ns & $22.89 \pm 1.37$ & $25.58 \pm 1.53$ & -10.52 & 3.46 \\
\hline s. fore leg cut & $55.06 \pm 0.93$ & ns & $54.54 \pm 1.26$ & $52.27 \pm 1.53$ & +4.34 & 2.30 \\
\hline t. loin cut & $16.60 \pm 0.56$ & ns & $17.79 \pm 0.89$ & $17.45 \pm 1.00$ & +1.95 & 0.14 \\
\hline u. thoracic cage cut & $4.07 \pm 0.26$ & ns & $4.78 \pm 0.33$ & $4.67 \pm 0.36$ & +2.36 & 0.05 \\
\hline \multicolumn{7}{|c|}{$\begin{array}{l}\text { Side bone weight distribution between cuts expressed as percentage dissected side } \\
\text { bone weight occurring in: }\end{array}$} \\
\hline v. hind leg cut & $42.22 \pm 0.33$ & $\mathrm{~ns}$ & $43.05 \pm 0.50$ & $42.30 \pm 0.56$ & +1.77 & 2.00 \\
\hline w. fore leg cut & $15.87 \pm 0.12$ & $*$ & $16.25 \pm 0.18$ & $15.69 \pm 0.20$ & +3.57 & 8.85 \\
\hline x. loin cut & $23.71 \pm 0.37$ & ns & $23.36 \pm 0.60$ & $23.81 \pm 0.67$ & -1.89 & 0.55 \\
\hline y. thoracic cage cut & $18.20 \pm 0.31$ & ns & $17.34 \pm 0.47$ & $18.20 \pm 0.53$ & -4.73 & 2.95 \\
\hline
\end{tabular}

* : significant; ns: non significant

a, b, c and d: calculated as percentage of slaughter weight; e, f, g and h: calculated as percentage of jointed side weight; i, j and k: calculated as percentage of dissected side weight. $\mathrm{n}, \mathrm{o}, \mathrm{p}$ and q: calculated as percentage of the muscle in cut to the muscle in side; $r, \mathrm{~s}, \mathrm{t}$ and $\mathrm{u}$ : calculated as percentage of the fat in cut to the fat in side; $v, w, x$ and $y:$ calculated as percentage of the bone in cut to the bone in side. 